\title{
Five Primary care teams facing the Covid Pandemic : analysis of territorial mobilizations
}

François-Xavier Schweyer, Laure Fiquet, Sébastien Fleuret, Marie Blois, Marie Garnier, Antoine Géal and Aline Ramond-Roquin

\section{CpenEdition}

1 Journals

Electronic version

URL: https://journals.openedition.org/rfst/1268

DOI: $10.4000 /$ rfst. 1268

ISSN: 2492-3672

Publisher

Espaces et SOciétés (UMR 6590)

\section{Electronic reference}

François-Xavier Schweyer, Laure Fiquet, Sébastien Fleuret, Marie Blois, Marie Garnier, Antoine Géal and Aline Ramond-Roquin, "Five Primary care teams facing the Covid Pandemic : analysis of territorial mobilizations", Revue francophone sur la santé et les territoires [Online], Pandemic, crises and perspectives: territorial readings of Covid-19. Online since 14 June 2021, connection on 19 June 2021. URL: http://journals.openedition.org/rfst/1268 ; DOI: https://doi.org/10.4000/rfst.1268

This text was automatically generated on 19 June 2021 .

\section{cc) (†) (อ)}

La Revue francophone sur la santé et les territoires est mise à disposition selon les termes de la Licence Creative Commons Attribution - Pas d'Utilisation Commerciale - Partage dans les Mêmes Conditions 4.0 International. 


\title{
Five Primary care teams facing the Covid Pandemic : analysis of territorial mobilizations
}

\author{
François-Xavier Schweyer, Laure Fiquet, Sébastien Fleuret, Marie Blois, \\ Marie Garnier, Antoine Géal and Aline Ramond-Roquin
}

1 This article offers a spatialized reading of the COVID 19 pandemic by analysing its management by five primary care teams organized in multi-professional health homes (MSPs) in two regions, the pays de la Loire and Brittany. Based on the exploitation of intermediate results of a research program (Concert-MSP) that studies the forms and modalities of multi-professional consultation in MSPs, the analysis combines two territorial dimensions: the local territories in which MSP teams have adapted to the unprecedented situation and the regional territories that have been the spaces for the deployment of health security measures decided by the State.

2 The results show the diversity of territorial contexts (territories with a rural, intermediate or urban trend) of the 5 MSPs studied that have resulted in varied operating situations seen as combination of territorial factors more or less favourable to the proposed coordinated exercise (focus on maintaining a local care offer, focus on professionals cooperation, focus on community). Using these categories, the article analysis the management of the health crisis in primary care, by taking the regional territory as a space for the implementation of a national plan.

3 Two different approaches are observed to mobilizing local actors and developing necessary compromises to be made locally to establish state authority. Basically, the regional health agency in Pays de la Loire favoured an approach where patients suspected of COVID-19 infection were referred to dedicated places, separated from the usual places of care, to provide medical consultations and, in a second stage, diagnostic tests. The Brittany agency, for its part, has deployed an approach based on existing organizations after listing them, and carried out follow-up work. Medical teams have set up new organizations in relation with these differentiated regional strategies but also in relation with local specificities. The analysis of the activities of health 
professionals within the framework of MSPs mobilizes a new definition of the notion of territory, of a sociological nature. This is professional territory, in which each professional group works to define a specific perimeter of intervention bounded by borders that sometimes impede cooperation (Schweyer, 2004). The Covid crisis has shaken up these territories by renewing the issue of patient care. Within each team, a double question arose: who supports what? With whom? Indeed, MSPs teams have changed their care and cooperation practices to manage the crisis. Their mobilization enabled the emergence or strengthening of local self-help networks, and questionned the professional territories and the symbolic division of labour, thus helping to give new roles and establish new practices. While the existence of a working collective has been facilitated in developing appropriate responses, the central role of physicians has been rather strengthened. The expansion of relational networks and the interknowledge between actors in the territories could be among the achievements of the crisis. But the drawing of territories do not depend only on professions, they are negotiated with the state, as recalled by the management of the crisis where certain professions have been prevented from practising in liberal practice (speech therapists, dieticians, podiatrists, physiotherapists, etc.). For those who had a mixed liberalhospital activity, they increased the time in structure. The physiotherapists experienced a forced withdrawal from their practice on the advice of the College Board, with instructions to maintain urgent care at home (which definition has sometimes been discussed within the teams). Some called patients for advice and posted videos on Youtube. Some salaried professionals (ex. public health nurse) have ceased their activity within the MSP at the request of their employer. Other professionals have been given new roles. Pharmacists, for example, have had new missions given by the state such as identifying domestic violence.

4 The day-to-day activity of the teams has been substantially modified by the priority given to the management of the epidemic. Activities such as multi-professional consultation, have been abandoned or adapted to the context of the crisis. It should be remembered that the two regions involved in the analysis were relatively spared from the epidemic. Not all elements of the crisis management system have been deployed and the teams mobilized to receive infected patients have been moderately exposed. This lesser pressure has no doubt fostered a space for local initiatives to respond to the crisis. However, the territorial differentiation observed in the management of the crisis can be explained in large part in the configuration of the territory of each MSP. For example, MSP 1 backed by a proximity hospital was able to manage the crisis on its own, which was impossible for MSP 4 both close to a "leading" hospital and whose population served faces more difficulties in access to care. MSP 3 away from a hospital and in conjunction with an ARS departmental delegation encouraging local initiatives was able to manage the Covid system fairly autonomously. 


\section{AUTHORS}

\section{FRANÇOIS-XAVIER SCHWEYER}

Sociologue, Professeur de l'Ecole des Hautes Etudes en Santé Publique, Centre Maurice Halbwachs UMR 8097

\section{LAURE FIQUET}

MD,1- Univ Rennes, Département de médecine générale, 2- CHU Rennes, Inserm, CIC 1414

[(Centre d'Investigation Clinique de Rennes)], F-35000 Rennes, France.

\section{SÉBASTIEN FLEURET}

Géographe, DR CNRS, ESO - UMR 6590 ESO, Université d'Angers

\section{MARIE BLOIS}

Interne, Département de médecine générale, UFR Santé, Univ d'Angers, France

\section{MARIE GARNIER}

Interne, Département de médecine générale, UFR Santé, Univ d'Angers, France

\section{ANTOINE GÉAL}

Interne, Univ Rennes, Département de Médecine Générale, F-35000 Rennes, France

\section{ALINE RAMOND-ROQUIN}

MD, PhD, 1- MCU, Département de médecine générale, UFR Santé, Univ d'Angers, France et 2Irset (Institut de recherche en santé, environnement et travail) - UMR_S 1085, Université d'Angers, Université de Rennes, Inserm, EHESP, F-49000 Angers, France 